\title{
Managing Functional and Innovative Entrepreneurship Centres for Global Competitiveness in Public Universities in South-South, Nigeria
}

\author{
Godwin Poi (PhD., FCA, FCNA) \\ Director of Centre for Entrepreneurship \\ Head of Department of Business Administration \\ Faculty of Social and Management Sciences \\ University of Africa, Toru-Orua, (UAT). Bayelsa State, Nigeria \\ E-mail: godwinpoi@yahoo.co.uk
}

Received: April 28, 2021

doi:10.5296/jebi.v8i1.18684
Accepted: May 20, 2021

Published: May 27, 2021

\begin{abstract}
This study investigated approaches and challenges of managing functional and innovative Entrepreneurship Centres for global competitiveness in public universities in South-South, Nigeria. The study adopted descriptive survey design and was guided by two research questions and two hypotheses. Stratified random sampling technique was used to select 487 from the population of 9,735 academic staff in the 14 public universities in South-South, Nigeria. Data was collected using a survey questionnaire instrument which was validated for reliability at 0.88 . Mean and standard deviation were used to analyse the research questions while z-test was used to test the hypotheses at 0.05 level of significance. The findings showed that in South-South, Nigeria were not globally competitive. Some of the approaches that could be deployed to improve their global competitiveness included using diverse means to enhance entrepreneurial behaviours and mindsets of the students and adopting extensive use of visuals, digital tools and multimedia to enhance their creativity. The challenges identified include inadequate funding, poor university-industry partnership on Research \& Development and inadequate infrastructural facilities. It is recommended that Entrepreneurship Centres in public universities in South-South, Nigeria should be adequately funded and they should adopt relevant approaches in order to become globally competitive.
\end{abstract}

Keywords: Entrepreneurship Centres, Functional, Innovation, Management, Global Competitiveness, Creativity, Interactive Teaching

\section{Introduction}

Nigeria recently introduced mandatory theory and skills acquisition entrepreneurship education in all tertiary institutions in the country. This was considered to be an innovation in the educational system to equip graduates to be business-minded upon graduation and boost nationwide job and wealth creation. The National Universities Commission (NUC) oversaw its implementation with the aim of tackling graduate unemployment and enhance the productive capacity of Nigerian youths, which should position them properly for global 
competitiveness. A very important component of the successful implementation of the policy was to establish centres of entrepreneurship in all the tertiary institutions in Nigeria irrespective of whether they are public or private universities. These Entrepreneurship Centres are to be headed by directors who are meant to coordinate entrepreneurship programmes in their respective universities.

To be successful, the management of functional and innovative Entrepreneurship Centres implies coordinating and directing the programmes and activities of these centres in such a manner that they achieve the purpose for which they were set up in the first place. Successful functional Entrepreneurship Centres are institutions that are viable and committed to impacting business knowledge and skills to students nurturing and expanding these knowledge and skills to allow them to become successful entrepreneurs and function as competent and acceptable adults in the society. The focus of Entrepreneurship Centres is to change the mindset of students from job seekers to job and wealth creators when they graduate.

Innovative Entrepreneurship Centres need to be continuously creative in the introduction and improvement of new ideas leading to better ways of doing things (Barringer \& Ireland, 2006; Pretorius, Millard \& Kruger, 2005; Bosma \& Harding, 2007; Baldacchino, 2009). They invest time and resources in research, improvement of technology and knowledge management. They organize workshops, seminars and conferences for their staff and students as a means of updating and upgrading their knowledge and skills. Having functional and innovative Entrepreneurship Centres in public universities in Nigeria is relevant and central to the production of young successful entrepreneurs and the development of businesses, in order to enhance economic growth and development as well as productive capacity for global competitiveness.

The world is now a global village making it easier for the movement of goods and services across national boundaries through constant innovations in the information and communications technology. This is highly advantageous for productive economies who now have access to wider markets for their products and services. Global competitiveness requires a country to have the ability to achieve and sustain high rates of economic growth usually measured by increase in their gross domestic product (GDP) (Poi \& Ekekwe, 2017; Poi, 2020). The private sector needs to be viable and adequately encouraged by government to sustainably drive the economy. Functional and innovative Entrepreneurship Centres should enhance the growth of Small and Medium Enterprises (SMEs) and also intensify Research and Development (R\&D) activities. Despite the implementation of the entrepreneurship education for a few years now, the graduate and general unemployment rates in Nigeria still remain high (PWC, 2020; Suttern, 2016). University graduates are still chasing very small number of job opportunities on offer instead of creating jobs and wealth by themselves. This re-enforces the urgent need to examine ways that functional and innovative Entrepreneurship Centres could be managed, for example, in public universities in South-South Nigeria, for self-reliance, job creation, increased productivity and global competitiveness. This study examined fourteen approaches and seven challenges to determine the factors affecting managing functional and innovative Entrepreneurship Centres in South-South Nigeria for global competitiveness. 
Universities as citadels of learning and ivory towers occupy central positions in knowledge generation and human capital development that are required for economic growth and overall development of society. Human capital development is achieved through improving the quality of human beings and making them relevant to their societies through education, training and skills acquisition. Entrepreneurship Centres in universities are expected to impact entrepreneurial mindsets that will help students take advantage of business opportunities available and become entrepreneurs as well as job and wealth creators. It is a major concern therefore that after several years of introducing entrepreneurship education and establishing and operating Entrepreneurship Centres in all the universities in Nigeria, majority of the university graduates still job-hunt with their certificates seeking non-existent jobs instead of becoming entrepreneurs thereby creating jobs and wealth. This raises the question of how effectively these centres are managed and the extent to which they are functional and innovative in their approaches in achieving global competitiveness. These are the problems that form the thrust of this paper for investigation with the focus on the approaches needed and challenges faced in managing functional and innovative Entrepreneurship Centres for global competitiveness in public universities in South-South Nigeria.

\section{Aim and Objectives of the Study}

The aim of this study was to investigate the management of functional and innovative Entrepreneurship Centres for global competitiveness in public university in South-South Nigeria.

The specific study objectives were to:

1. determine approaches needed in managing functional and innovative Entrepreneurship Centres for global competitiveness in public universities in South-South Nigeria.

2. identify the challenges that confront the utilization of these approaches in managing functional and innovative Entrepreneurship Centres for global competitiveness in public universities in South-South Nigeria.

\subsection{Research Questions}

The following research questions guided the study:

1. What approaches are needed in managing functional and innovative Entrepreneurship Centres for global competitiveness in public universities in South-South Nigeria?

2. What are the challenges of managing functional and innovative Entrepreneurship Centres for global competitiveness in public universities in South-South Nigeria?

\subsection{Hypotheses}

The following hypotheses were postulated and tested at 0.05 level of significance.

Ho1: There is no significant difference in responses between male and female academic staff on the approaches needed in managing functional and innovative Entrepreneurship Centres for global competitiveness in public universities in South-South Nigeria.

Ho2: There is no significant difference in responses between male and female academic staff on the challenges of managing functional and innovative Entrepreneurship Centres for global competitiveness in public universities in 
South-South Nigeria.

\section{Literature Review}

Theories of human capital (HCT) have long propounded that formal education is highly instrumental and necessary to improve the productive capacity of a population. Human capital theorists such as Schultz (1960, 1971), Becker (1992), Psacharapoulos and Woodhall (1997) have long espoused these theories with other proponents such as Gillies (2015), Klein $\&$ Cook $(2006)$, Poi $(2017,2018)$ also finding that an educated population is a productive one. Human capital theory emphasizes how education increases the productivity and efficiency of workers by increasing the level of cognitive stock of economically productive human capability which is a product of innate abilities and investment in human beings. The provision of formal education, training and skill acquisition programmes is seen as a productive investment in human capital, which the proponents of the theory consider to be equal or even more important than physical capital.

Babalola (2003) argued that the rationale behind human capital development is threefold:

i. that the new generation must be given the appropriate parts of the knowledge which has already been accumulated by previous generations;

ii. that the new generation should be taught how existing knowledge should be used to develop new products, to introduce new processes and production methods and social services; and

iii. that people must be encouraged to develop entirely new ideas, products, processes and methods through creative approaches.

This argument is apt and pertinent to this study because Entrepreneurship Centres in universities are education centres established to formally inculcate entrepreneurial skills (human capital development) in the students in order to help them to become creative, productive, risk-taking, investors and active participants in their socio-economic environment. Entrepreneurship Centres are expected to nurture and develop young entrepreneurs who will invest their skills and resources in productive ventures for their economic well-being and that of their society. Their training should enhance the productive capacity of the nation, economic growth and development. The global competitiveness of these centres speaks to their effectiveness and ability to train and produce quality students upon graduation. In effect, whether or not their graduates can compete in the world and be entrepreneurs who can create wealth and jobs rather than job seekers.

The Federal Government of Nigeria, through the universities regulatory authority, the National Universities Commission (NUC), directed all Nigerian universities to compulsorily establish entrepreneurship development centres from the 2007/08 academic session. The entrepreneurship curriculum was designed for full implementation as part of university entrepreneurship education programmes (Adejimola \& Olufunmilayo, 2009). These centres were established through clear directives from the NUC. Funds were meant to be provided to support the programmes and activities of these centres. They were required to set up small and medium scale resource centres, SME clubs, organize business plan competitions, organize networking events, industrial visits and excursions as well as role-model interactions 
and mentoring. These activities and the provision of entrepreneurship education were seen as important steps for building an innovation culture and creating entrepreneurial individuals and organizations which in turn can create jobs and wealth leading to economic growth. In theory at least, this should help to enhance quality of life of the people (UNCTAD, 2010; Poi, 2020). All these were directed towards changing the mindset and culture of those university graduates who did not clearly understand or view business and entrepreneurial activities favourably.

The indications are however that these Entrepreneurship Centres are not sufficiently effective and functional in pursuing these goals. This is evidenced by the rising instead of falling graduate unemployment rate in Nigeria (Suttern, 2016) despite the introduction of entrepreneurship education system since 2007. While in no way justifying these vices, the vulnerable unemployed youths have used this as excuses for their restiveness, agitations and other unacceptable criminal activities (Ojule, 2020).

In 2014, a Federal Ministry of Education study found that a staggering 53\% of graduates were unemployed, $30 \%$ graduates were underemployed and a paltry $3 \%$ of them were owners of businesses (Dangana, 2014). A significantly high proportion at $69 \%$ stated that the lack of jobs accounted for their restiveness and agitations. This is a serious socio-economic challenge which can be addressed through what Drucker (1984) described as an entrepreneurial society in which innovation and entrepreneurship are normal, steady and continual. The argument is that innovation and entrepreneurship can provide the way forward in solving the global challenges of the $21^{\text {st }}$ century, building sustainable development, creating jobs, generating renewed economic growth and advancing human welfare. Thus, the Entrepreneurship Centres in the public universities in South-South, Nigeria, should inculcate survival values, marketable and self-reliance skills in their students as part of human capital development suitable for enterprises. Equipping these students with relevant contemporary labour market and entrepreneurial skills will help them to compete favourably with graduates from other universities in the world therein creating global competitiveness. It will not only enhance entrepreneurship and business innovations but potentially also achieve sustainable development.

Sulaiman (2010) opined that the main objective of entrepreneurship education is economic empowerment. This can be achieved through having functional and innovative entrepreneurial development centres in the universities. Ojule (2020) further emphasised the justification and appropriateness of involving public universities as interventionist mechanism, through entrepreneurship education, to address youth unemployment which is one of the greatest threats to societal stability. There is therefore, an urgent need to fully implement entrepreneurship education and provide every necessary support needed by entrepreneurial development centres to make them efficient, effective, functional and innovative.

Management is the effective organization and utilization of the human and material resources in a particular system for the achievement of predetermined goals (Ihekwoaba \& Maduike, 2016). The various functions of management such as planning, organizing, leading and controlling the human and non-human resources are very critical in having functional and innovative Entrepreneurship Centres in public universities. A functional and innovative 
entrepreneurship centre is one that equips the students with the relevant entrepreneurial knowledge and skills, entrenching entrepreneurship behaviours and business start-up support required to influence the existing organizational structures, institutional mission, traditions and organizational models and governance. Achieving this will involve a lot of stakeholders and policy makers. Inculcating entrepreneurial behaviours in the young graduates requires support from policy makers at various levels to address the issue of entrepreneurship education and management, create appropriate legal and fiscal frameworks to support entrepreneurship in filling market gaps (Akpomi \& Ikpesu, 2020).

Entrepreneurship Centres in public universities serve as centres for incubation, innovation, technology diffusion, applied research and focal points for collaboration among researchers, students, companies and entrepreneurs. Institutional leadership is critical for setting up the management, governance and culture of entrepreneurship in universities.

While there are various roles for Entrepreneurship Centres such as marketing and income generation (Mass \& Jones, 2017), the role envisaged here is more of skills and human capacity building enabling the graduands to become entrepreneurs. Hannon (2013) and Lackeus (2015) therefore listed the roles of entrepreneurial development centres in public universities as follows:

- enhancing entrepreneurial behaviours and mindsets.

- Building self-confidence, efficiency and leadership in students.

- Enhancing creativity, innovation and ability to think "out of the box" to solve problems

- Teaching students how to manage complexity and unpredictability.

- Impacting basic business and financial skills (business literacy).

- Enhancing opportunity identification by students.

- Educating students on how to build, finance and grow ventures.

- Developing negotiation skills in students; and

- Helping students in building relationships, networks and social capital.

Adejimola and Olufunmilayo (2009) posited further that these roles can be achieved through interactive, learner centred pedagogies; use of multi-disciplinary programmes approach, project case studies, games, simulations and business plan competitions; extensive use of visuals, digital tools and multimedia; learning through hands-on experiential learning (trial and error); projects, internships with start-ups; mentoring and coaching and interactions with entrepreneurs. It is very important to support these approaches with adequate career guidance for entrepreneurship programmes in public universities in Nigeria. They also observed that for an individual to have a fulfilled life, the type of entrepreneurship activity he engages in has an important role to play. Also, Oluwole (2003) observed that among students, there still exists confusion and ignorance about entrepreneurial activities, careers and choices. This calls for employing career counsellors to advise students into various entrepreneurial activities, especially in a situation that demands for matching students with the demands of their prospective ecosystem.

There are however several factors that militate against and therefore become major challenges and hurdles in the way in managing functional and innovative Entrepreneurship Centres in public universities in Nigeria for global competitiveness. Okebukola (2011) and 


\section{Macrothink}

Kofarmata (2014) conceptualized the following areas of concern:

- Perception of relevance and meaning of entrepreneurship in higher education, and developing as a shared institutional vision, identity and consensus.

- Organizational transformation and re-organization of knowledge, people and opportunity.

- Ideological threats, notions of capitalism and the demise of academic autonomy.

- Curricula controls on content and assessment through internal structures and external agencies.

- Positioning within an institutional structure either inside, or academic faculties or colleges or external organs.

Okebukola (2011) identified:

- The heavy initial financial outlay of implementing entrepreneurship education.

- Short supply of trained personnel to deliver quality entrepreneurship education.

- Constraints in the business environment for starting up small businesses.

- Poor university-industry partnership. Industries do not trust the quality of graduates from the universities and the relevance of university-based research.

Other studies have also identified other issues such as inadequate teaching facilities and methods (Oloibi, 2017; Ebong \& Nwakudu, 2017) as well as funding (Akpomi \& Ikpesu, 2020) as few of the biggest challenges of entrepreneurial development centres across universities based in Nigeria. From the above listing of diverse challenges, it can be seen that there are a number of challenges that must be surmounted for these entrepreneurial development centres to be globally competitive against their counterparts around the globe, especially in terms of producing successful graduate entrepreneurs.

\section{Methodology}

The study adopted descriptive survey design. The population of the study consisted of all the 9,735 academic staff (5,841 male and 3,894 female) in the 14 public universities in South-South Nigeria (Source: Academic Planning Units of these Universities, 2018 Report). A sample of 487 (292 male and 195 female) academic staff representing 5\% of the population was drawn through stratified random sampling technique. A survey questionnaire entitled: "Approaches and Challenges of Managing Functional and Innovative Entrepreneurship Centres Questionnaire (ACMFIECQ)" developed by the researcher was used for data collection. The instrument had 21 items and was properly validated with a reliability index of 0.88 using the test-retest method. Mean, standard deviation, mean set and rank order were used to analyse the research questions while z-test at 0.05 level of significance was used to test the hypotheses.

\section{Results}

\subsection{Research Question One}

What approaches are needed in managing functional and innovative Entrepreneurship Centres for global competitiveness in public universities in South-South Nigeria? 
Table 1. Scores and ranking of responses of male and female academic staff on approaches to managing Entrepreneurship Centres

\begin{tabular}{|c|c|c|c|c|c|c|c|c|}
\hline \multirow[t]{4}{*}{$\mathrm{S} / \mathrm{N}$} & \multirow{4}{*}{$\begin{array}{l}\text { Approaches needed in managing } \\
\text { functional and } \\
\text { Entrepreneurship Centres }\end{array}$} & \multirow{2}{*}{\multicolumn{2}{|c|}{$\begin{array}{c}\text { Male } \\
\text { Academic } \\
\text { Staff }\end{array}$}} & \multirow{2}{*}{\multicolumn{2}{|c|}{$\begin{array}{l}\text { Female } \\
\text { Academic } \\
\text { Staff }\end{array}$}} & \multirow{3}{*}{$\begin{array}{l}\text { Mean } \\
\text { Sets } \\
\mathrm{X}_{1} \\
+\mathrm{X}_{2}\end{array}$} & \multirow{4}{*}{$\begin{array}{l}\text { Rank } \\
\text { Order }\end{array}$} & \multirow[t]{4}{*}{ Decision } \\
\hline & & & & & & & & \\
\hline & & \multicolumn{2}{|c|}{$\mathrm{N}=292$} & \multicolumn{2}{|c|}{$\mathrm{N}=195$} & & & \\
\hline & & $\bar{X}_{1}$ & $S D_{1}$ & $\bar{X}_{2}$ & $\mathrm{SD}_{2}$ & 2 & & \\
\hline 1. & $\begin{array}{l}\text { Using diverse means to enhance } \\
\text { entrepreneurial behaviours and mindsets } \\
\text { among the students. }\end{array}$ & 3.08 & 0.60 & 3.10 & 0.59 & 3.09 & $5^{\text {th }}$ & Agree \\
\hline 2. & $\begin{array}{l}\text { Using interactive learner-centred } \\
\text { pedagogies to build self-confidence, } \\
\text { self-efficiency and leadership in the } \\
\text { learners. }\end{array}$ & 3.02 & 0.64 & 2.98 & 0.69 & 3.00 & $13^{\text {th }}$ & Agree \\
\hline 3. & $\begin{array}{l}\text { Using multidisciplinary programmes } \\
\text { approach, project case studies, games, } \\
\text { simulations and business plan } \\
\text { competitions. }\end{array}$ & 3.06 & 0.65 & 3.00 & 0.66 & 3.03 & $11^{\text {th }}$ & Agree \\
\hline 4. & $\begin{array}{l}\text { Adopting extensive use of visuals, } \\
\text { digital tools and multimedia to enhance } \\
\text { creativity, innovation and student's } \\
\text { ability to think "out of the box" to solve } \\
\text { problems. }\end{array}$ & 3.12 & 0.54 & 3.02 & 0.65 & 3.07 & $7^{\text {th }}$ & Agree \\
\hline 5. & $\begin{array}{l}\text { Adopting learning by doing/hands-on } \\
\text { through projects and internships. }\end{array}$ & 3.08 & 0.60 & 3.08 & 0.62 & 3.08 & $6^{\text {th }}$ & Agree \\
\hline 6. & $\begin{array}{l}\text { Having high level of partnership } \\
\text { between Entrepreneurship Centres and } \\
\text { industries on R\&D. }\end{array}$ & 3.00 & 0.67 & 3.04 & 0.63 & 3.02 & $12^{\text {th }}$ & Agree \\
\hline 7. & $\begin{array}{l}\text { Providing adequate coaching, mentoring } \\
\text { and interactions with local and } \\
\text { international entrepreneurs. }\end{array}$ & 3.07 & 0.62 & 3.01 & 0.62 & 3.04 & $10^{\text {th }}$ & Agree \\
\hline 8. & $\begin{array}{l}\text { Equipping students with skills for } \\
\text { managing complexity } \\
\text { unpredictability. }\end{array}$ & 3.07 & 0.62 & 3.05 & 0.64 & 3.06 & $8^{\text {th }}$ & Agree \\
\hline 9. & Equipping students with basic business & 3.09 & 0.59 & 3.10 & 0.56 & 3.10 & $4^{\text {th }}$ & Agree \\
\hline
\end{tabular}


skills such as opportunity identification,

finance and negotiation skills.

10. Ensuring that students acquire the skills $\begin{array}{lllllll}3.04 & 0.58 & 3.06 & 0.64 & 3.05 & 9^{\text {th }} & \text { Agree }\end{array}$ of how to build finance and grow their own ventures.

11. Equipping students with skills of building relationships, networks and social capital.

12. Providing adequate career guidance for entrepreneurship programmes.

13. Providing start-up capital or connecting $\begin{array}{lllllll}3.12 & 0.55 & 3.09 & 0.61 & 3.11 & 3^{\text {rd }} & \text { Agree }\end{array}$ graduating students to sources of start-up capital.

14. Inadequate provision of technology commercialization.

Table 1 shows that items 1 to 13 in the rank order of $1^{\text {st }}$ to $13^{\text {th }}$ all had average mean scores greater than the criterion mean of 2.50 with an overall average mean score of 3.02 . They were all therefore accepted as approaches needed in managing functional and innovative Entrepreneurship Centres for global competitiveness in public universities in South-South Nigeria. Item 14 on the provision of technology commercialisation however had an average mean score of 2.36 which is less than the criterion mean of 2.50. It was therefore rejected as an approach needed in managing functional and innovative Entrepreneurship Centres for global competitiveness in public universities in South-South Nigeria. The average mean scores of 3.03 and 3.01 for male and female academic staff respectively with a combined average mean of 3.02 were all above the criterion mean and is an indication that both male and female academic staff agreed on the approaches needed in managing functional and innovative Entrepreneurship Centres for global competitiveness in public universities in South-South Nigeria.

Therefore, the approaches needed in managing functional and innovative Entrepreneurship Centres for global competitiveness in public universities in South-South Nigeria include: using diverse means to enhance entrepreneurial behaviours and mindsets among the students; using interactive learner-centred pedagogies to build self-confidence, efficiency and leadership in the learners; using multidisciplinary programmes approach, project case studies, games, simulations and business tools and multimedia to enhance creativity, innovation and students ability to think "out of the box" to solve problems; adopting learning by doing/hands-on through projects and internships; having high level of partnership between Entrepreneurship Centres and industries on $\mathrm{R} \& \mathrm{D}$; providing adequate coaching, mentoring 
and interactions with local and international entrepreneurs; equipping students with skills for managing complexity and unpredictability; equipping students with basic business skills such as opportunity identification, finance and negotiation skills; ensuring that students acquire the skills of how to build, finance and grow their own ventures; equipping students with skills of building relationships, networks and social capital; providing adequate career guidance for entrepreneurship programmes and providing start-up capital or connecting graduating students to sources of start-up capital. The inadequacy of the provision of technology for commercialisation was not considered to be an approach and was therefore rejected.

\subsection{Research Question Two}

What are the challenges of managing functional and innovative Entrepreneurship Centres for global competitiveness in public universities in South-South Nigeria?

Table 2. Scores and ranking of responses of male and female academic staff on the challenges of managing Entrepreneurship Centres

\begin{tabular}{|c|c|c|c|c|c|c|c|c|}
\hline \multirow[t]{5}{*}{$\mathrm{S} / \mathrm{N}$} & Items & \multirow{4}{*}{\multicolumn{2}{|c|}{$\begin{array}{c}\text { Male } \\
\text { Academics } \\
\text { Staff } \\
\mathrm{N}=292\end{array}$}} & \multirow{3}{*}{\multicolumn{2}{|c|}{$\begin{array}{l}\text { Female } \\
\text { Academic } \\
\text { Staff }\end{array}$}} & \multirow{4}{*}{$\begin{array}{c}\text { Mean } \\
\text { Sets } \\
\mathrm{X}_{1}+ \\
\mathrm{X}_{2} \\
\end{array}$} & \multirow{5}{*}{$\begin{array}{l}\text { Rank } \\
\text { Order }\end{array}$} & \multirow[t]{5}{*}{ Decision } \\
\hline & \multirow{4}{*}{$\begin{array}{l}\text { Challenges that confront the } \\
\text { utilization of these approaches in } \\
\text { managing functional and innovative } \\
\text { Entrepreneurship Centres }\end{array}$} & & & & & & & \\
\hline & & & & & & & & \\
\hline & & & & & 195 & & & \\
\hline & & & $S D_{1}$ & $\bar{X}_{2}$ & $S D_{2}$ & 2 & & \\
\hline 1. & $\begin{array}{lll}\text { Inadequate } & \text { funding } & \text { of }\end{array}$ & 3.01 & 0.68 & 3.04 & 0.71 & 3.03 & $6^{\text {th }}$ & Agree \\
\hline & Entrepreneurship Centres & & & & & & & \\
\hline 2. & Poor university-industry partnership. & 3.10 & 0.66 & 3.08 & 0.69 & 3.09 & $4^{\text {th }}$ & Agree \\
\hline 3. & Inadequate supply of trained & 3.16 & 0.61 & 3.13 & 0.63 & 3.15 & $1^{\text {st }}$ & Agree \\
\hline & $\begin{array}{l}\text { personnel to deliver quality } \\
\text { entrepreneurial education. }\end{array}$ & & & & & & & \\
\hline 4. & Issues of policy frameworks and their & 3.14 & 0.63 & 3.11 & 0.64 & 3.13 & $2^{\text {nd }}$ & Agree \\
\hline & $\begin{array}{l}\text { implementation to support easy } \\
\text { star-up of small and medium } \\
\text { enterprises. }\end{array}$ & & & & & & & \\
\hline 5 . & $\begin{array}{l}\text { Pedagogical issues and methods of } \\
\text { assessment used by Entrepreneurship }\end{array}$ & 3.06 & 0.67 & 3.07 & 0.66 & 3.07 & $5^{\text {th }}$ & Agree \\
\hline & Centres & & & & & & & \\
\hline 6. & Unwillingness of students to & 1.96 & 0.74 & 1.94 & 0.75 & 1.95 & $7^{\text {th }}$ & Disagreed \\
\hline & $\begin{array}{l}\text { participate in skills acquisition } \\
\text { programmes. }\end{array}$ & & & & & & & \\
\hline 7. & $\begin{array}{l}\text { Inadequate availability of } \\
\text { infrastructural facilities. }\end{array}$ & 3.12 & 0.64 & 3.08 & 0.67 & 3.10 & $3^{\text {rd }}$ & Agree \\
\hline & Average mean and standard deviation & 2.94 & 0.66 & 2.92 & 0.68 & 2.93 & & \\
\hline
\end{tabular}

Table 2 shows that items $1,2,3,4,5$ and 7 in the rank order of $1^{\text {st }}$ to $6^{\text {th }}$ had weighted mean set scores that were all greater than the criterion mean of 2.50 . They were therefore accepted as the challenges that confront the utilization of these approaches in managing functional and innovative Entrepreneurship Centres in public universities in South-South Nigeria. Item 6 had 
weighted mean set score of 1.95 which is less than the criterion mean of 2.50. It was therefore rejected as one of the challenges that confront the utilization of these approaches in managing functional and innovative Entrepreneurship Centres in public universities in South-South Nigeria.

The average weighted mean scores of 2.94 and 2.92 for male and female academic staff respectively with a combined average mean of 2.93 were above the criterion mean and show that both categories of staff have similar responses on the challenges of managing functional and innovative Entrepreneurship Centres in public universities in South-South Nigeria.

Thus, the challenges that confront the utilization of these approaches in managing functional and innovative Entrepreneurship Centres for global competitiveness in public universities in South-South Nigeria include: inadequate funding; poor university-industry partnership; inadequate supply of trained personnel; issues of policy frameworks and their implementation; pedagogical issues and methods of assessment and inadequate availability of infrastructural facilities.

\subsection{Test of Hypotheses One}

There is no significant difference in the responses between male and female academic staff on the approaches needed in managing functional and innovative Entrepreneurship Centres for global competitiveness in public universities in South-South Nigeria.

Table 3. Z-test of the difference between the average mean scores of male and female academic staff on the approaches in managing functional and innovative Entrepreneurship Centres

\begin{tabular}{lcccccccl}
\hline Gender & $\mathrm{N}$ & $\bar{X}$ & $\begin{array}{l}\text { Std } \\
\text { Dev. }\end{array}$ & Df & z-cal & z-critical & $\begin{array}{c}\text { Level of } \\
\text { sign. }\end{array}$ \\
Male & 292 & 3.03 & 0.61 & & & & & \\
& & & & 485 & & \pm 1.96 & 0.05 & $\begin{array}{l}\text { Not sision } \\
\text { hypothesis accepted }\end{array}$ \\
& & & & & 1.28 & & & \\
Female & 195 & 3.01 & 0.63 & & & & & \\
\hline
\end{tabular}

Table 3 shows a summary of the mean, standard deviation and z-test of difference between the responses of male and female academic staff on the approaches needed in managing functional and innovative Entrepreneurship Centres for global competitiveness in public universities in South-South Nigeria. The calculated z-test used in testing the hypothesis was 1.28 while the critical z-value was \pm 1.96 at 485 degree of freedom using 0.05 level of significance. The $z$-calculated value was less than the $z$-critical value. Therefore, the null hypothesis of no statistically significant difference between the mean scores of male and female academic staff on the approaches needed in managing functional and innovative Entrepreneurship Centres for global competitiveness in public universities in South-South Nigeria was therefore accepted.

\subsection{Test of Hypotheses Two}

There is no significant difference in responses between male and female academic staff on the challenges of managing functional and innovative Entrepreneurship Centres for global 
competitiveness in public universities in South-South Nigeria.

Table 4. Z-test of difference between the average mean scores of male and female academic staff on the challenges of managing functional and innovative Entrepreneurship Centres.

\begin{tabular}{lcccccccl}
\hline Gender & $\mathrm{N}$ & $\bar{X}$ & $\begin{array}{l}\text { Std } \\
\text { Dev. }\end{array}$ & Df & z-cal & z-critical & $\begin{array}{c}\text { Level of } \\
\text { sign. }\end{array}$ \\
\hline Male & 292 & 2.94 & 0.66 & & & & & \\
& & & & 485 & & \pm 1.96 & 0.05 & $\begin{array}{l}\text { Not significant. Null } \\
\text { hypothesis accepted }\end{array}$ \\
& & & & & 1.06 & & & \\
Female & 195 & 2.92 & 0.68 & & & & & \\
\hline
\end{tabular}

Table 4 shows a summary of average mean standard deviation and z-test of difference between the responses of male and female academic staff on the challenges that confront the utilization of these approaches in managing functional and innovative Entrepreneurship Centres for global competitiveness in public universities in South-South Nigeria. The calculated z-test score 1.06 while the critical z-value was \pm 1.96 at 485 degree of freedom using 0.05 level of significance. The z-calculated value was therefore less than the $z$-critical value. Thus, the null hypothesis of no statistically significant difference between the mean scores of male and female academic staff on the challenges that confront the utilization of these approaches in managing functional and innovative Entrepreneurship Centres for global competitiveness in public universities in South-South Nigeria was accepted.

\section{Discussion of Findings}

This study examined managing functional and innovative Entrepreneurship Centres for global competitiveness in public universities in South-South Nigeria. The results showed that the approaches needed in managing functional and innovative Entrepreneurship Centres for global competitiveness in public universities in South-South Nigeria include: using diverse means to enhance entrepreneurial behaviours and mindsets among the students; using interactive learner-centred pedagogies to build self-confidence, efficiency and leadership in the learners; using multidisciplinary programmes approach, project case studies, games, simulations and business plan competitions; adopting intensive use of visual, digital tools and multimedia to enhance creativity, innovation and students ability to think "out of the box" to solve problems; adopting learning by doing/hands on through projects and internships; having high level of partnership between Entrepreneurship Centres and industries on R\&D; providing adequate coaching, mentoring and interactions with local and international entrepreneurs; equipping students with skills for managing complexity and unpredictability; equipping students with basic business skills such as opportunity identification, finance and negotiation skills; ensuring that students acquire the skills of how to build, finance and grow their own ventures; equipping students with skills of building relationships, networks and social capital; providing adequate career guidance for entrepreneurship programmes and providing start-up capital or connecting graduating students to sources of start-up capital. These findings support the broad findings in Ojule (2020), Ebong and Nwakudu (2017), Okebukola (2011) and Akpomi and Ikpesu (2020). In summary, they also found that 


\section{MInstitute ${ }^{\text {Mink }}$}

Entrepreneurship Centres in public universities in South-South Nigeria are not managed effectively. The centres do not as yet adopt the needed approaches that will make them functional and innovative.

To be functional and innovative, they have to strive harder to achieve the goals for which they were established; namely to reduce unemployment through gainful engagement of graduates in entrepreneurial ventures and activities to create jobs and wealth. Graduates of public universities in South-South Nigeria should start up their own businesses and become self-employed rather than roaming the streets with their certificates in search of white-collar jobs. The centres need to adopt innovative approaches to impact the relevant entrepreneurial skills into their students in order to help them to become globally competitive.

It is noteworthy to state that, in line with the findings in Dangana (2014) and Suttern (2016), graduate unemployment rate in South-South Nigeria has been on the increase after more than ten years of the implementation of entrepreneurship education in public universities and the establishment of Entrepreneurship Centres in tertiary institutions in the country. Most of these centres are not properly equipped with relevant facilities to acquire the necessary skills. There is a paucity of well-trained lecturers to enhance the inculcation of entrepreneurial skills. Building entrepreneurial behaviours and mindsets in our youths should be a collective responsibility of all the stakeholders in education and national economic development. There should be collaboration between public universities and local and international industries on research and development (R\&D). This will enhance innovation and global competitiveness. Entrepreneurship Centres should engage properly trained career guidance counsellors in their entrepreneurship programmes so that students' interest can be identified and nurtured. The students should be encouraged to have savings in order to invest their own money in addition to their time and energy where their passions lie for better productivity and business sustainability.

There is marked difference between acquiring entrepreneurial skills and translating these acquired skills into credible business ventures or activities. Entrepreneurship Centres should be actively involved in advising and guiding the students to appropriate sources of capital for starting up and running viable businesses. They need to liaise with suitable and relevant agencies to provide policies aimed at creating enabling business environment for young entrepreneurs.

This study has also revealed that the challenges that confront the utilization of these approaches in managing functional and innovative Entrepreneurship Centres in public universities in South-South Nigeria for global competitiveness include: inadequate funding; poor university-industry partnership; inadequate trained personnel; poor policy frameworks and their implementation; inadequate infrastructure; and pedagogical/assessment issues. These findings corroborate the findings of Oliobi (2017), Adejimola and Olufumilayo (2009) and Sulaiman (2010). Specifically, their studies had also found that adequate funding for the purchase of equipment and relevant facilities remains a major challenge in the management of Entrepreneurship Centres in universities. This is remarkably similar to the situation in public universities in South-South Nigeria. Most of these centres are not viable and cannot boast of adequate internally generated revenue (IGR) for self-sustenance. They depend almost entirely on funds from government which are notoriously inadequate in meeting the 
needs of these centres for producing graduates that can compete favourably globally. This is also complicated by the dearth of qualified and trained lecturers. Many of the lecturers lack the skills, expertise and the requisite practical experience to positively impact the students through adequate preparation of instructions and choice of the right pedagogical and assessment methods.

Public universities in South-South Nigeria are also not adequately partnering and collaborating with industries within and outside their localities in the areas of research and development (R\&D), students' internships and personnel and institutional capacity building and development. All these factors contribute to poor management of Entrepreneurship Centres. In fact, they almost always offer theoretical rather than hands-on and practise-oriented entrepreneurship education in public universities in South-South Nigeria. Furthermore, there is poor policy framework and implementation. Government needs to formulate favourable fiscal policies to create a conducive business friendly environment for the growth of young entrepreneurs and small and medium enterprises (SMEs). An enabling business environment is necessary in encouraging people to go into business. The environment in many parts of Nigeria is harsh for the survival of businesses. There are very often too many entry barriers and constrains. Many of these, such as numerous local taxes, are even illegal with no statutory backing for the extortions. There is epileptic or lack of power supply, bad roads for transportation and commuting, insecurity, illegal task forces and frequent changes of government policies. All these factors raise the costs of doing business in Nigeria and also adversely impact upon the management of functional and innovative Entrepreneurship Centres thereby rendering them ineffective and non-competitive.

\section{Conclusion}

Entrepreneurship Centres in public universities in South-South Nigeria have enormous task of entrenching entrepreneurial behaviours and mindsets in their students in order to help become creative and self-reliant. This will help to reduce graduate unemployment and contribute to economic growth and development. It will also increase the ability of the university graduates to compete favourably globally. These goals can be achieved through ensuring that these Entrepreneurship Centres are functional and innovative by adopting appropriate approaches that are relevant and effective in impacting entrepreneurial skills and attitudes to the students. It will encourage them to establish and run their own businesses and create jobs for themselves and others.

However, managing functional and innovative Entrepreneurship Centres for global competitiveness in public universities in South-South Nigeria through the utilization of approaches could be significantly impeded by a number of challenges. It is therefore necessary for the top management of these public universities and the federal and state governments to take pragmatic measures towards ensuring that Entrepreneurship Centres are functional, innovative and effective in achieving their goals and objectives and they should tackle any challenges that may be obstacles to their progress.

\section{Recommendations}

Based on the findings of this study, the following recommendations were made: 


\section{Macrothink Institute ${ }^{\mathrm{m}}$}

- Entrepreneurship Centres in public universities in South-South Nigeria should be adequately funded to enable them provide relevant modern technologies, instructional facilities, basic infrastructure and employ relevant qualified instructors/lecturers.

- Entrepreneurship Centres in public universities in South-South Nigeria should establish partnership and collaboration with relevant stakeholders such as local and international entrepreneurs, local and international industries, government agencies and research institutions in order to exploit the common synergy for mutual benefits.

- Entrepreneurship Centres in public universities in South-South Nigeria should adopt creative approaches in managing functional and innovative Entrepreneurship Centres to enable them fulfil their mandates.

\section{References}

Adejimola, A. S., \& Olufumilayo, T. (2009). Spinning off an entrepreneurship culture among Nigerian university students: Prospects and challenges. African Journal of Business Management, (3), 80-88.

Akpomi, M. E., \& Ikpesu, O. C. (2020). Entrepreneurship in tertiary education. In S.O. Nwafor \& S. O. Oluwuo (Eds.), Management of education for sustainable national development in Nigeria (pp 81-96). Port Harcourt. University of Port Harcourt Press

Baldacchino, L. (2009). Entrepreneurial Creativity and Innovation. Paper presented at the First International Conference on Strategic Innovation and Future Creation Monday 23 March 2009. Grand Hotel Excelsior, Floriana - MALTA

Barringer, B. R., \& Ireland, R. D. (2006). Entrepreneurship: Successfully launching new ventures. New Jersey: Pearson Prentice Hall.

Becker, G. (1992). Human capital and the economy. Proceedings of the American Philosophical Society, 136(1), 85-92.

Bosma, N., \& Harding, R. (2007). Global entrepreneurship monitor: GEM 2006 results. MA, USA: Babson. College and UK: London Business School.

Retrieved from www.gemconsortium.org in June 2007

Babalola, J. B. (2003). Budget preparation and expenditure control in education. In J.B. Babalola (Ed). Basic text in educational planning. Ibadan: Awemark Industrial Printers.

Dangana, E. A. (2014). Resources management in entrepreneurship practice: TeTfund capacity building workshop on entrepreneurship education and training in public tertiary institutions. November/December $27-02$.

Drucker, P. F. (1984). Innovation and entrepreneurship: Practice and Principles. California: Harper and Row, Publishers Inc.

Ebong, J. M., \& Nwakudu, G. N. (2017). Managing entrepreneurship education at university level in Rivers State in an era of economic recession. African Journal of Education Research and Development, 9(1), 10-20.

Gillies D. (2015). Human Capital Theory in Education. In: Peters M. (eds) Encyclopedia of Educational Philosophy and Theory. Springer, Singapore. https://doi.org/10.1007/978-981-287-532-7_254-1

Hannon, P. D. (2013). Why is the entrepreneurial university important? Journal of Innovation Management, 1(2), 10-17.

Ihekwoaba, C. K. C., \& Maduike, I. M. (2016). Managing school inputs to improve 
productivity. In S. O. Oluwuo \& J. D. Asodike (Eds.), Managing schools for productivity: Emerging perspectives. Port Harcourt: Pearl Publishers International.

Klein, P., \& Cook, M. (2006). T.W. Schultz and the Human-Capital Approach to Entrepreneurship. Review of Agricultural Economics, 28, 344-350. 10.2307/3877178.

Kofarmata, A. I. (2014). Management of entrepreneurship development centre: Structure, operation, autonomy and domestication. Tetfund capacity building workshop on entrepreneurship education and training in public tertiary institutions. November/December, pp 144-147

Lackeus, M. (2015). Entrepreneurship in education: What, why, when, how: Entrepreneurship 360 background paper supported by European Commission, LEED and OECD.

Maas, G., \& Jones, P. (2017). The Role of Entrepreneurship Centres. Retrieved from https://10.1007/978-3-319-47892-0_2

Ojule, L. C. (2020). Reinventing public universities as entrepreneurial centres for youth economic empowerment in Nigeria. In S. O. Nwafor \& S. O. Oluwuo (Eds.), Management of education for sustainable national development in Nigeria (pp 593-599). Port Harcourt: University of Port Harcourt Press.

Okebukola, P. (2011). Entrepreneurship in university education: Beyond talk. $27^{\text {th }}$ Convocation Lecture, University of Port Harcourt, Nigeria.

Oliobi, G. I. (2017). Assessment of the implementation of entrepreneurship education programme in public universities in South-East, Nigeria. Unpublished Ph.D Thesis, University of Port Harcourt, Nigeria.

Oluwole, T. (2003). A synopsis of disciplines and careers. Akure: Orteeyz Printers and Publishers.

Poi, G. (2017). Aligning policy goals and outcomes in developing human capital: a case study of the Rivers State of Nigeria overseas scholarships programme. Published Ph.D Thesis, Cardiff Metropolitan University, Wales, UK. Available from: British Library EThOS.

Poi, G. (2018). Analysis of the Rate of Successful Graduation of Government-Funded overseas scholarship programme in Rivers State. Review of Education, University of Nigeria, Nsukka. Volume 30. pp $208-228$

Poi, G. (2020). Analysis of Entrepreneurial Skills Necessary for Economic Growth Perspectives from Selected Universities in Rivers State of Nigeria. IOSR Journal of Business and Management. International Organization of Scientific Research. e-ISSN: 2278-487X, p-ISSN: 2319-7668. Volume 22, Issue 8. Ser. II, pp25-33

Poi, G., \& Ekekwe, E. N. (2017). From adversity to prosperity: Lessons for Nigeria from China and India. Port Harcourt Journal of Social Sciences, 7(1), 288-304.

Pretorius, M., Millard, S. M., \& Kruger, M. E. (2005). Creativity, innovation and implementation: Management experience, venture size, life cycle stage, race and gender as moderators. South African Journal of Business Management, 36(4), 55-68.

Psacharapoulos, G., \& Woodhall, M. (1997). Education for development: An analysis of investment choices. New York: Oxford University Press.

PwC. (2020). Nigeria Economic alert. Unemployment rate expected to hit 30\%. Retrieved 24 April 2021 from https://www.pwc.com/ng/en/assets/pdf/economic-alert-september-2020.pdf Schultz, T. (1960). Capital formation by education. The Journal of Political Economy, 68(6), 
571-583.

Schultz, T. (1971). Education and productivity. Washington, DC: National Commission on Productivity.

Sulaiman, H. (2010). Entrepreneurship education for development. International Journal of Education Studies, (1), 47-52.

Suttern (2016). Nigeria Graduate Report. Covenant university Repository. Retrieved from http://eprints.covenantuniversity.edu.ng/8124/1/Nigeria\%2BGraduate\%2BReport.pdf

UNCTAD. (2010) United Nations Conference on Trades and Development Entrepreneurship education, innovation and capacity-building in developing countries. Geneva: UNCTAD Secretariat.

\section{Copyright Disclaimer}

Copyright for this article is retained by the author (s), with first publication rights granted to the journal.

This is an open-access article distributed under the terms and conditions of the Creative Commons Attribution license (http://creativecommons.org/licenses/by/3.0/). 